\title{
Powrót do ekfrazy. Próba systematyzacji oraz propozycja typologii
}

Rozalia Słodczyk

TEKSTY DRUGIE 2018, NR 5, S. 352-371

DOI: $10.18318 /$ td.2018.5.21

\section{Niejednoznaczna ekfraza}

Ekfraza zajmuje ważną pozycję w studiach intersemiotycznych i, ogólniej - komparatystycznych i intermedialnych, szczególnie od lat 9o. XX wieku. Co problematyczne, badacze prezentują różne podejścia metodologiczne, a sama ekfraza „stała się w najnowszych publikacjach pewnego rodzaju «wspólnym workiem» (umbrella term), określającym wszelkie relacje i związki między sztuką poetycką i wizualną"1. Problem niejasnej konotacji terminu ekfraza dostrzega m.in. znamienita badaczka zagadnienia, Ruth Webb², wyróżniająca cztery jego ogólne znaczenia równocześnie funkcjonujące w badaniach: 1) znaczenie i zakres, jakie termin miał w starożytności,

1 R. Popowski Starożytny przewodnik po neapolitańskiej pinakotece, w: Filostrat Starszy Obrazy, przeł. R. Popowski, Prószyński i S-ka, Warszawa 2004 , s. 33 .

2 R. Webb Ekphrasis, Imagination and Persuasion in Ancient Rhetorical Theory and Practice, Ashgate, Farnham 2009, s. 6; tejże Ekphrasis Ancient and Modern. Thelnvention of a Genre, "Word \& Image" 1999 Vol. 15 Iss. 1, s. 7 .

\section{Rozalia Słodczyk}

- dr, absolwentka Kolegium MISH UW (filologia polska i historia sztuki) oraz Katedry Italianistyki UW. Napisała doktorat na temat Ekfraza i hypotypoza. Interferencje literatury i malarstwa w prozie włoskiej i eseistyce polskiej XX wieku. Interesuje się relacjami werbalno-wizualnymi, malarstwem nowożytnym, teorią i krytyką sztuki, praktyką przekładu. Kontakt: rslodczyk@ wp.pl 
stosowany do tych tekstów, co w starożytności; 2) termin odnoszony do tych starożytnych przykładów, które są opisami dzieł sztuki; 3) jakikolwiek antyczny tekst o sztuce; 4) tekst o sztuce, dowolnego gatunku, z dowolnego kręgu kulturowego i epoki. Z kolei Bernhard Scholz podkreśla nieokreślony status terminologiczny pojęcia ekfrazy: termin określający figurę (albo technikę) retoryczną, ćwiczenie retoryczne, gatunek literacki, forma odnosząca się do makrostruktury tekstu, forma podawcza (mode of writing, jak opis czy dialog) ${ }^{3}$, modus literacki (literary mode $e^{4}$, jakość ekspresji werbalnej) ${ }^{5}$.

Ze względu na konfuzje terminologiczne i wielość definicji - czasem zbyt ogólnych, nieprecyzyjnych albo znów nadmiernie zawężających - pojęcie ekfrazy domaga się doprecyzowania, aby mogło być operatywne. Chcę rozumieć ekfrazę jako zjawisko semantyczno-pragmatyczne, jako formę wypowiedzi (nie tylko literackiej), nie zaś ograniczać się do perspektywy retorycznej albo genologicznej ${ }^{6}$. Chciałabym zacząć od wskazania koncepcji kilku współczesnych badaczy ekfrazy oraz na antyczne źródła tej formy wypowiedzi.

\section{Wybrane koncepcje ekfrazy}

Jak uważa Webb, termin ekphrasis w znaczeniu „opis dzieła sztuki” zaczął funkcjonować dopiero od II połowy XX wieku. Pierwszym badaczem,

3 B. Scholz 'Sub oculos subiektio'. Quintilian on Ekphrasis and Enargeia, w: Pictures into Words. Theoretical and Descriptive Approaches to Ekphrasis, ed. by V. Robillard, E. Jongeneel, Vu University Press, Amsterdam 1998, s. 74 .

4 J.A.W. Heffernan Ekphrasis and Representation, "New Literary History” 1991 Vol. 22 No. 2, s. 298.

5 Por. podejmujący zagadnienie niejasnego statusu ekfrazy artykuł włoskiej badaczki: V. Scuderi Modi d'ékphrasis. Un'introduzione, w: L'immagine rubata. Seduzioni e astizuie dell'ékphrasis, a cura di A. Valtolina, Bruno Mondadori, Milano 2007, s. 9-17.

6 Jako gatunek ma nieokreślone wyraźnie wyznaczniki; zwykle stanowi fragment innej wypowiedzi, a pojawia się we wszystkich rodzajach literackich, a także w formach uznawanych za nieliterackie (np. historia i krytyka sztuki) i tradycyjnie uchodzących za pograniczne (np. esej). Na gruncie polskich badań pojawiła się propozycja Bożeny Witosz "przywrócenie ekfrazie statusu gatunku tekstu". B. Witosz Ekfraza w tekście użytkowym - w perspektywie genologicznej i dyskursywnej, w: Kulturowe wizualizacje doświadczenia, red. W. Boleckiego, A. Dziadek, Wydawnictwo IBL PAN, Warszawa 2010, s. 165, 166. Badaczka interpretuje ekfrazę jako gatunek wypowiedzi nie tylko, kiedy jest ona autonomiczną formą, ale także kiedy występuje niesamodzielnie, włączona w „inne struktury werbalne”, gdyż kryterium samodzielności tekstowej, w jej ujęciu, nie jest warunkiem bycia gatunkiem. Witosz włącza ekfrazę w obręb gatunków mowy.

7 R. Webb Ekphrasis, Imagination..., s. 10. 
który posługiwał się terminem w wąskim znaczeniu, był zdaniem badaczki Leo Spitzer, który nie wspomina w swojej definicji o retorycznej tradycji ekfrazy:

poetycka deskrypcja dzieła sztuki malarskiej lub rzeźbiarskiej, która to deskrypcja pociąga za sobą, zgodnie ze słowami Théophile'a Gautier, „une transposition d'art”, reprodukcję, za pośrednictwem słów, zmysłowo postrzegalnych objets d'art (ut pictura poesis). ${ }^{8}$

Następuje tu zawężenie znaczenia ekfrazy do opisu dzieła sztuki, a nawet bardziej: do opisu poetyckiego (i tylko obrazu albo rzeźby), reprodukującego w słowie zmysłowo postrzegane dzieło sztuki. Dla Spitzera to forma, w której można oddzielić obiektywny opis od fragmentów interpretacyjnych, będących wynikiem oddziaływania dzieła na poetę. De facto przywołana definicja tworzy rdzeń większości późniejszych ujęć. Zacznę od dwóch skrajnych koncepcji ekfrazy, jednej ekstremalnie zawężającej pojęcie (Hagstrum) i drugiej maksymalnie poszerzającej jego stosowalność (Krieger).

Jean Hagstrum, określając to, co nazwalibyśmy poezją ekfrastyczną, mówi o poezji ikonicznej. Pojmuje ekfrazę inaczej niż to ogólnie przyjmowane: jego ekfraza to prozopopeja, jako że ekfrazą chce nazywać „ową specjalną własność oddawania głosu i języka obiektom artystycznym, które w przeciwnym razie pozostałyby nieme"', a powołuje się przy tym na etymologię słowa - ekphrazein jako „przemówić”, ,powiedzieć w pełni”. Podobną, choć mniej radykalną koncepcję przynosi John Hollander, który zawęża odniesienie ekfrazy do poezji, a za ekfrastyczne uważa te wiersze, w których podmiot mówiący zwraca się do dzieł sztuki, opisuje je, pozwala im przemówić. Wskazuje też bezpośrednio sposoby odwołania się do obrazu w wierszach XIX- i XX-wiecznych twórców: „zwracanie się do obrazu, skłanianie go do mówienia, interpretowanie go, medytowanie o momencie oglądania go"10.

8 L. Spitzer The "Ode on a Grecian urn" or content vs. metagrammar, "Comparative Literature" 1955 Vol. 7 No. 3, s. 207. Trzeba doprecyzować, że to Huysmans w latach 80. XIX wieku użył pojęcia transpositions d'art, aby określić sposób, w jaki Odilon Redon w swoich pracach uchwycił nastrój tekstów Poego i Baudelaire'a. J.H. Hagstrum The Sister Arts: the Tradition of Literary Pictorialism and English Poetry from Dryden to Gray, University of Chicago Press, Chicago 1958, s. 18, przypis 34.

10 J. Hollander The Gazer's Spirit: Poems Speaking to Silent Works ofart, University of Chicago Press, Chicago 1995, s. 4 . 
O ile ekfraza Hagstruma stosuje się do niewielkiego skrawka twórczości literackiej, o tyle koncepcja Murray'a Kriegera jest wszechobejmująca. Ujęcie Kriegera pozostaje silnie powiązane z myśleniem Lessinga, który dzielił sztuki na czasowe (literatura) i przestrzenne (sztuki plastyczne), kontrastował temporalne następstwo w języku i zastygłą momentalną wizję w malarstwie, dynamikę i statyczność, mediacyjność kodu werbalnego i bezpośredniość kodu wizualnego ${ }^{11}$. Ekfraza miałaby być rozpięta między tymi dwiema formułami wypowiedzi. Sztuki plastyczne stanowiłyby metaforę nie tylko werbalnej reprezentacji doświadczenia wizualności, ale też kształtowania każdej wypowiedzi językowej, która staje się ogólną formą ekfrazy i chce oddać w słowie wizualność, kształt ${ }^{12}$. Krieger podaje różne definicje ekfrazy, poszerza je, by ostatecznie mówić o „zasadzie ekfrastycznej" (ekphrastic principle), która miałaby charakteryzować literaturę jako taką ${ }^{13}$. Ekfraza staje się szukaniem słownego ekwiwalentu dla każdego wizualnego obrazu, niekoniecznie artefaktu plastycznego - badacz chce widzieć ekfrazę jako malowanie słowami (word-painting). Taka koncepcja ekfrazy jest jednak zbyt ogólna (a miejscami niejasna i niespójna), aby miała wartość operacyjną. Była krytykowana przede wszystkim za nadmierne rozciągnięcie znaczeniowe. James Heffernan wskazywał, że Krieger tak rozszerza pojęcie ekfrazy, że nie odnosi się ono do żadnych określonych form literackich ${ }^{14}$.

Sam Heffernan jest autorem niezwykle popularnej i sentencyjnie lakonicznej definicji ekfrazy: „ekfraza to werbalna reprezentacja wizualnej

11 Por. W. Steiner The Temporal Versus the Spatial Arts, w: tejże The Colors of Rhetoric. Problems in the Relation Between Modern Literature and Painting, The University of Chicago Press, ChicagoLondon 1982, s. 33-50.

12 M. Krieger The Problem of Ekphrasis: Image and Words, Space and Time - and the Literary Work, w: Pictures into Words..., s. 4, 5. Mitchell tak ujmuje esencję projektu Kriegera: „For Krieger, the visual arts are a metaphor, not just for verbal representation of visual experience, but for the shaping of language into formal patterns that 'still' the movement of linguistic temporality into a spatial, formal array. Not just vision, but stasis, shape, closure, and silent presence ('still' in the other sense) are the aims of this more general form of ekphrasis"; W.J.T. Mitchell Ekphrasis and the Other, w: tegoż Picture Theory. Essays on Verbal and Visual Representation, University of Chicago Press, Chicago 1994, s. 153-154.

13 M. Krieger Ekphrasis and the Still Movement of Poetry; or, Laokoön Revisited, w: The Poet as Critic, ed. by F.P.W. McDowell, Northwestern University Press, Evanston 1967, s. 22.

14 J.A.W. Heffernan Museum of Words. The Poetics of Ekphrasis from Homer to Ashbery, The University of Chicago Press, Chicago 1993, s. 2. 
reprezentacji"15. Chce, aby jego definicja była konkretna i pozwoliła wyodrębnić jednoznacznie teksty literackie, które ją spełniają, a zarazem żeby okazała się na tyle szeroka, aby objąć i starożytną, i współczesną ekfrazę - od Homera do Ashbery'ego, jak pisze badacz. Takie wyznaczenie konotacji ekfrazy nie jest jednak satysfakcjonujące ze względu na rozległe pole denotacyjne - obejmuje bardzo różne przypadki opisów artefaktów. Wielu badaczy odnosi się jednak do tej formuły, nieznaczenie ją modyfikując. Przykładowo W.J.T. Mitchell przyjmuje za Heffernanem rozumienie ekfrazy jako werbalnej reprezentacji wizualnej reprezentacji, dodając, że choć w historii różnie definiowano ekfrazę - jako udzielanie głosu niememu obiektowi, retoryczny opis dzieła sztuki, sugestywny opis mający na celu stawianie „przed oczami duszy” danego obiektu czy nawet tak szeroko, jak rozumie ekfrazę Krieger, jako ogólną zasadę literatury - to funkcjonalne jest

użycie ekfrazy jako modelu określającego możliwość osiągnięcia przez sztukę literacką formalnych, strukturalnych wzorców i sugestywnego reprezentowania szerokiego zakresu doświadczeń percepcyjnych, szczególnie doświadczenia wzrokowego. ${ }^{16}$

Claus Clüver, niemiecki badacz kwestii interartystycznych, proponuje z kolei następującą definicję ekfrazy: „Ekfraza jest werbalną reprezentacją prawdziwego lub fikcyjnego tekstu skomponowanego w niewerbalnym systemie znakowym"17. Jego regulacja terminu poszerza więc pole ekfrazy. Badacz

Tamże, s. 3. W swoim wcześniejszym artykule sformułował taką samą definicję, ale zamiast "visual representation" użył wyrażenia "graphic representation", które nie było tak jednoznaczne i chwytliwe. Por. J.A.W. Heffernan Ekphrasis and Representation, s. 299.

W.J.T. Mitchell Ekphrasis and the Other, s. 154, przypis 9. Mitchell przedstawia też swoją teorię trzech etapów fascynacji ekfrazą (co można interpretowaćjako trzy różne podejścia do zagadnienia ekfrazy): ekfrastyczna obojętność (ekphrastic indifference; wyrażająca się przekonaniem, że ekfraza nigdy nie będzie reprezentować danego obiektu tak, jak jego przedstawienie wizualne); ekfrastyczna nadzieja (ekphrastic hope; charakteryzuje ją poczucie, że dzięki wyobraźni ekfraza pozwala nam ujrzeć to, co opisuje); ekfrastyczny strach (ekphrastic fear; wiążący się z poczuciem, że różnica między oboma rodzajami reprezentacji, werbalnej i wizualnej, może się zatrzeć w odbiorze). Koncepcję Mitchella przybliżają m.in. B. Swoboda Zniewalająca siła ekfrazy (rzecz o zmaganiach słowa i obrazu w poglądach W.J.T. Mitchella), „Przestrzenie Teorii” 2011 nr 16, s. 41-50 oraz G. Jankowicz Nieobecna ekfraza, w: Kulturowe wizualizacje doświadczenia, s. 210-225.

17 C. Clüver Ekphrasis Reconsidered. On Verbal Representations of Non-verbal Texts, w: Interart Poetics: Essays on the Interrelations of the Arts and Media, ed. by U.-B. Lagerroth et al., Rodopi, Amsterdam-Atlanta 1997, s. 26. 
modyfikuje formułę Heffernana, którą uważa za niepełną i ograniczającą: wprost nazywa ekfrazami także nieliterackie werbalizacje (np. krytyka artystyczna, eseje), a ponadto rozszerza przedmiot ekfrazy: obejmuje ona nie tylko dzieła sztuki (także np. plakaty czy fotografię), nie tylko dzieła sztuki realnie istniejące i nie tylko dzieła sztuki wizualnej (również architekturę, taniec, muzykę). Dodatkowo dla Clüvera warunkiem do mówienia o ekfrazie jest pojawienie się efektu Anschaulichkeit (obrazowość, sugestywność) ${ }^{18}$ : „ekfraza jest etymologicznie i tradycyjnie właśnie nazwą enargetycznej deskrypcji" ${ }^{\prime \prime}$. Ostatecznie więc chce niejako zawrócić historię i przywrócić ekfrazie sens, jaki miała w starożytności ${ }^{20}$, co wydaje się jednak nieefektywnym zabiegiem, przede wszystkim dlatego, że współczesna ekfraza różni się od starożytnej.

\section{Retoryczna i literacka tradycja ekfrazy w antyku}

Ekphrasis w starożytności miała szerokie znaczenie. Starożytni retorzy, posługując się tym terminem, nie mieli na myśli przede wszystkim albo nawet w ogóle opisu dzieła sztuki (ówczesne definicje ekfrazy dają po prostu ogólną definicję opisu). Nie każdy też tekst dotyczący dzieła sztuki nazywano w antyku (zarówno w tradycji łacińskiej, jak i greckiej) ekfrazą. Dlatego Filostrat Młodszy we wstępie do swoich Eikones (mniejszej serii Obrazów) odwołuje się do Eikones swojego dziada Filostrata Starszego jako do „ekfraz dzieł malarskich”, a nie po prostu „ekfraz”.

Wyraz ēkphrasis pochodzi od starogreckiego czasownika phrāzo, który ma wiele znaczeń: „zwracam uwagę na coś”,,,pokazuję",,wyjaśniam”,,,pielęgnuję styl”,,polecam”, ,rozważam”,,,spostrzegam" ${ }^{21}$. Ten, kto opisuje, powinien wykonać właściwie wszystkie te działania - przedstawić i objaśnić dany obiekt

18 Taki tytuł nosi książka Gottfrieda Willemsa dotycząca związków słowa i obrazu: Anschaulichkeit. Zu Theorie und Geschichte der Wort-Bild-Beziehungen und des literarischen Darstellungsstils, Max Niemeyer Verlag, Tübingen 1989.

C. Clüver Quotation, Enargeia, and the Functions of Ekphrasis, w: Pictures into Words..., s. 42.

Zarazem badacz odpowiada w pewnym sensie avant la lettre na skargę Mario Klagera, który pisał, że tacy autorzy jak Krieger, Haffernan, Hollander i Mitchell omijają w swoich rozważaniach właściwości klasycznej (antycznej) ekfrazy i koncentrują się głównie na problemach podwójnej reprezentacji, jaką daje literacki opis dzieła sztuki. Por. M. Klager Introduction „ "Word \& Image” 1999 Vol. 15 No. 1, s. 1.

21 Por. hasła ekphrasis, enargeia, diatyposis w Glossary of Greek Rhetorical Terms Connected to Methods of Argumentation, Figures And Tropes From Anaximenes to Quintilian, ed. by R. Dean Anderson Jr., Peeters, Leuven 2000. 
w odpowiednim stylu i stosownym językiem, wyrazić jakąś myśl na temat przedmiotu zainteresowania, zwracając uwagę na rozmaite jego aspekty, a także pochwalić przedmiot deskrypcji. W ten sposób to, co opisywane, czyni się jasnym i zrozumiałym, a też przykuwa się uwagę odbiorców ${ }^{22}$. Prefiks ek- wskazuje z kolei na kompletność i dokładność. Ekfraza (bezokolicznik ekphrazein) znaczyła zatem pierwotnie: „pokazać bardzo wyraźnie”, „uczynić znanym i kompletnie jasnym”,,,wyjaśniać w pełni, zupełnie"23.W starożytnych źródłach retorycznych synonimami ekfrazy były enargeia, hypotyposis i diatyposis oznaczające sugestywny opis, stawiający przed oczami (por. łac. formuła sub oculis subiectio) jak żywą opisywaną rzecz. Łacińskim odpowiednikiem ekfrazy byłoby nie tyle descriptio, ile explicatio - szczegółowy, wyjaśniający opis, apelujący do zmysłu wzroku i wyobraźni, oraz evidentia - obrazowość, wyrazistość (przekazu) ${ }^{24}$.

Ekfraza została zdefiniowana w starożytnych podręcznikach do retoryki. W czasach hellenistycznych należała do progymnasmata ${ }^{25}$, czyli wstępnych ćwiczeń przygotowawczych dla uczniów greckich szkół retorycznych edukujących elity. Progymnasmata składały się z definicji pojęć i wskazówek dotyczących tworzenia danych form, które następnie mogły być wykorzystywane jako części składowe dużych kompozycji, tj. kompletnych mów

Shadi Bartsch, pisząc o opisach artefaktów w antycznych tekstach prozatorskich, zwraca uwagę na obecność interpretatora dzieła malarskiego, wprowadzonego do tekstu jako jeden z bohaterów, odkrywającego i wyjaśniającego głębokie znaczenie obrazu, bez czego widz (zarówno intradiegetyczny, jak i ekstradiegetyczny) nie zrozumiałby artefaktu. S. Bartsch Decoding the Ancient Novel. The Reader and the Role of Description in Heliodorus and Achilles Tatius, Princeton University Press, Princeton 1989, s. 40-79.

Objaśnienie terminu daje m.in. F. Graf Ekphrasis: Die Entstehung der Gattung in der Antike, w: Beschreibungskunst - Kunstbeschreibung. Ekphrasis von der Antike bis zur Gegenwart, hrsg. von G. Boehm, H. Pfotenhauer, Wilhelm Fink Verlag, München 1995, s. 143-155. O znaczeniu pojęcia pisze też R. Popowski Starożytny przewodnik..., s. 33 oraz W. Juszczak Ekfraza poetycka wantycznej Grecji (przykłady wybrane), Wydawnictwo Neriton, Warszawa 2012, s. 10.

Por. hasła descriptio, explicatio, evidentia w Oxford Latin Dictionary, ed. by P.G.W. Glare et al., Oxford University Press, Oxford 1968; hasło ekphrasis Mario Klarera w: Routledge Encyclopedia of Narrative Theory, ed. by D. Herman, M. Jahn, M.-L. Ryan, Routledge, London-New York 2010, s. 133-134; A. Gorzkowski „Ut pictura verba...". Zagadnienie unaocznienia w retoryce starożytnej iwczesnonowożytnej, "Pamiętnik Literacki” 2001 z. 2, s. 37-59.

Por. Progymnasmata. Greckie ćwiczenia retoryczne i ich modelowe opracowanie, opracowanie, przekład i komentarz H. Podbielski, Towarzystwo Naukowe KUL, Lublin 2013 oraz R. Webb Ekphrasis, Imagination..., s. 39-86; o znaczeniu progymnasmata dla zrozumienia ekphrasis por. również S. Goldhill What is ekphrasis for?, "Classical Philology” 2007 Vol. 102 No. 1, s. 1-19. 
(publiczne przemowy, mowy sądowe, improwizowane deklamacje). Spośród zachowanych czterech greckich podręczników retoryki najstarszym i najobszerniejszym jest traktat autorstwa Teona z Aleksandrii (I/II wiek), który pisze: „ekfraza jest szczegółowym opisem, który w sposób wyrazisty stawia nam przed oczy przedstawianą rzeczywistość. Istnieją więc ekfrazy postaci, wydarzeń, miejsc i okresów czasu"26. Retor dodaje jeszcze jedną kategorię, tj. opisy sposobów, „takich jak dokładny sposób sporządzania sprzętów, uzbrojenia i machin wojennych"27, i podaje przykład opisu tarczy Achillesa w Iliadzie (XVIII pieśń, wersy 468-608; traktowany w nauce jako swoista arche-ekfraza) ${ }^{28}$. W głównej liście tematów ekfrazy opis dzieła sztuki nie stanowił nawet osobnej kategorii - był albo nieuwzględniany, albo pojawiał się tylko jako przykład. Co istotne, wśród zalet ekfrazy retor wymienia jasność i wyrazistość (plastyczność, sugestywność), które pozwalają „niemal widzieć przedstawiane rzeczy"29 - liczył się efekt, siła oddziaływania opisu na imaginację i emocje słuchaczy. Starożytne definicje ekfrazy to właśnie podkreślają, w odróżnieniu od współczesnych, które koncentrują się na przedmiocie opisu, jakim staje się artefakt. Ponadto ćwiczenie ekfrazy wiązało się nie tylko z umiejętnością deskrypcji, ale i z prowadzeniem narracji. Zdaniem Webb „fundamentalne rozróżnienie między narracją (rozwijającą się w czasie) a opisem (problematyczną werbalną reprezentacją przedmiotu, tworzącą «przerwę w narracji»), stanowiące podstawę tak wielu

26 Teon z Aleksandrii Wstępne ćwiczenia retoryczne, w: Progymnasmata. Greckie ćwiczenia retoryczne..., s. 96. Przez ekfrazę wydarzeń retor rozumie m.in. opis wojny, burzy, głodu, trzęsienia ziemi, przez ekfrazę miejsc - np. opisy portów, skalistych urwisk, miast, a przez ekfrazę okresów czasu - opisy pór roku czy świąt.

Tamże, s. 97.

Znamiennie, że Teona interesuje sposób (tropos, modus) opisu tarczy. Nie kwalifikuje tego opisu jako deskrypcji dzieła sztuki, ale wymienia go wśród opisów przygotowania wyposażenia militarnego. Homer bowiem buduje narrację dotyczącą powstawania tarczy, a niejako w konsekwencji tworzy opis tego, co Hefajstos na niej przedstawił (choć jest to oczywiście wyrafinowany zabieg literacki i retoryczny). Por. też U. Eco Tarcza i forma, w: tegoż Szaleństwo katalogowania, przeł. T. Kwiecień, Rebis, Poznań 2009, s. 8-13; C.S. Byre Narration, Description, and Theme in the Shield of Achilles, "Classical Journal” 1992 Vol. 88 No. 1, s. 33-42.

Teon z Aleksandrii, Wstępne ćwiczenia retoryczne..., s. 98. Inni autorzy traktatów retorycznych, tj. Hermogenesa z Tarsu (II/III wiek), Aftoniusza Sofisty (III/IV wiek) i Mikołaja z Myry (V wiek), właściwie powtarzają te ustalenia, rozumienie ekfrazy $\mathrm{i}$ istoty jej działania pozostaje u nich takie samo. Mikołaj z Myry jako jedyny wymienia obrazy i rzeźby jako przykładowe tematy ekfrazy. 
nowoczesnych koncepcji opisu i jego interpretacji, było ignorowane przez starożytnych teoretyków"30.

Kluczem do zrozumienia ekfrazy starożytnej są dwa słowa, pojawiające się w sformułowaniach na jej temat: gr. periēgèmatikos - szczegółowo opisujący, wyjaśniający, ale też oprowadzający, pokazujący drogę, i gr. enārgeia - wyraźny widok, naoczność wiązana z oświetleniem szczegółów, osiągana przez emocjonalny, obrazowy opis ${ }^{31}$. Mówca prowadzi odbiorców - pokazuje przedmiot w całości, ale też zwraca uwagę na jego konkretne aspekty, porządkuje i objaśnia to, co odbiorca ma „zobaczyć”. W tym sensie istniał związek między ekfrazą a reprezentacją wizualną, ale też między ekfrazą a efektem teatralnym - w opisie zjawisko czy obiekt umieszczano niczym na scenie, przed oczami publiczności² ${ }^{32}$ Badacze podkreślają, że w starożytności odbiorcy byli podatni na moc słyszanego słowa, a hellenistyczną kulturę charakteryzował rozwinięty „dyskurs widzenia”, dla którego podstawowe znaczenie miała zdolność wizualizacji, wywoływania obrazów (gr. phantasīa, łac. visione) ${ }^{33}$. Ekfraza miała stworzyć postrzegalny przedmiot, a słuchacza przemienić w widza ${ }^{34}$.

Tematykę ekfrazy podjęła także rzymska tradycja retoryczna. Poświęcił jej uwagę m.in. Marek Fabiusz Kwintylian, autor najwybitniejszego w starożytności dzieła z zakresu teorii i praktyki retorycznej - wydanej ok. 95 roku

30 R. Webb Ekphrasis Ancient and Modern..., s. 12. Oddzielenie opisu od narracji łatwiej zresztą przeprowadzić w teorii niż w praktyce, por. G. Genette Boundaries of Narrative, trans. by A. Levonas, "New Literary History” 1976 Vol. 8 No. 1, s. 1-13.

Enārgeia to w grece: 1. jasność, przejrzystość, 2. wyraźne postrzeganie, 3. wyraźny widok. Na temat enargei w antyku oraz renesansie, w literaturze, sztukach wizualnych i muzyce por. H.F. Plett Enargeia in Classical Antiquity and the Early Modern Age. The Aesthetics of Evidence, Brill, Leiden-Boston 2012. Na temat samej figury enargei oraz rozdzielenia enargei i energei por. B. Niebelska-Rajca ,"Enargeia" ${ }_{\text {„, }}$ energeia" w teoriach literackich renesansu i baroku, Wydawnictwo IBL PAN, Warszawa 2012; C. Ginzburg Descrizione e citazione, w: tegoż II filo e le tracce. Vero falso finto, Feltrinelli, Milano 2006.

R. Webb Ekphrasis, Imagination..., s. 83-84.

B. Scholz 'Sub oculos subiektio'..., s. 84-92. O tym aspekcie pisze obszernie Webb w rozdz. Phantasia: Memory, limagination and the Gallery of the Mind, w: tejże Ekphrasis, Imagination..., s. 107-130.

Por. S. Goldhill The Naive and Knowing Eye: Ecphrasis and the Culture of Viewing in the Hellenistic World, w: Art and Text in Ancient Greek Culture, ed. by S. Goldhill, R. Osborne, Cambridge University Press, Cambridge 1994, S. 197-223; J. Elsner Roman Eyes. Visuality \& Subjectivity in Art \& Text, Princeton University Press, Princeton-Oxford 2007. Wiązało się to z silnie obecną w antycznej kulturze tradycją oralną i aktywnym „czytaniem” tekstów przez słuchanie oraz towarzyszącą temu potrzebą nieustannego ćwiczenia pamięci (m.in. poprzez metody mnemotechniczne). 
Institutio oratoria ${ }^{35}$. Rzymski retor korzystał ze źródeł greckich, a jego komentarze na temat enargei są bliskie pojmowaniu tego terminu w greckiej tradycji retorycznej ${ }^{36}$. Chociaż Kwintylian nie używa słowa ekphrasis, jego koncepcja enargei (łac. evidentia) - sugestywnego opowiadania będącego ożywioną, rozwiniętą wersją prostej narracji, apelującą do wyobraźni i emocji odbiorców - jest zbieżna z rozumieniem ekfrazy przez greckich retorów. Kwintylian pisze o specjalnym rodzaju opisu dążącym do osiągnięcia efektu enargei - usłyszane (przeczytane) ma się zamienić w widziane; ważne są tu dwa powiązane ze sobą aspekty, tj. funkcja perswazyjna (pragmatyka wypowiedzi) i zdolność uobecniania ${ }^{37}$ :

61. [...] Stąd wśród ozdób należy umieścić enargeia, o której wspomniałem przy podawaniu zasad relacjonowania [IV 2, 63], jako że naoczność (evidentia), czy też, jak wolą inni, „uzmysłowienie” (repraesentatio), to coś więcej niż klarowność (perspicuitas): klarowność rozwiewa wątpliwości [jest oczywista], a enargeia niejako się ukazuje [narzuca się] (se ostendit). 62. To wielka zaleta wyrazić rzeczy, o których mówimy, jasno i tak, aby [słuchaczowi] zdawało się, że je postrzega. Mowa nie oddziałuje bowiem odpowiednio i nie osiąga pełnej mocy - tak jak powinna - jeśli ogranicza się do uszu, a sędzia odnosi wrażenie, że to, o czym się dowiaduje, jest $\mathrm{mu}$ opowiadane, a nie przedstawiane [odmalowywane] i ukazywane oczom umysłu ${ }^{38}$.

Po polsku ukazały się przekłady fragmentów tej pracy: Kształcenie mówcy [księgi I, II i X], przeł. i oprac. M. Brożek, Wydawnictwo Zakładu Narodowego im. Ossolińskich, Wrocław 1951 oraz Kształcenie mówcy [księgi VIII 6 - XII], wstęp, przekł. i przypisy S. Śnieżewski, Księgarnia Akademicka, Kraków 2012.

Por. I.H. Henderson Quintilian and the Progymnasmata, "Antike und Abendland" 1991 Vol. 37, s. 82-99.

Por. rozdz.: Ekphrasis and the Art of Persuasion oraz Enargeia: Making Absent Things Present, w: R. Webb Ekphrasis, Imagination...; K.S. Lamp "A City of Brick": Visual Rhetoric in Roman Rhetorical Theory and Practice, "Philosophy \& Rhetoric” 2011 Vol. 44 No. 2, S. 171-193.

Institutio oratoria, VIII 3, 61-62. Dziękuję za to tłumaczenie dr. Wojciechowi Wciórce z Instytutu Filozofii UW. Wskazany fragment z rozprawy Kwintyliana dokładnie analizuje Scholz w artykule 'Sub oculos subiektio'... Podobne stwierdzenia pojawiają się we wcześniejszych księgach Kształcenia mówcy: (IV 3,12-13) jasne i sugestywne słowo sprawia, że słuchaczowi zdaje się, że jest obecny przy zdarzeniach i odczuwa te same emocje, co ich naoczni świadkowie; $(\mathrm{VI} 2,32)$ enargeia/evidentia jest ekspozycją wizualnego, w efekcie wyczula zmysły odbiorcy jak wtedy, gdy ten faktycznie uczestniczy w jakichś zdarzeniach. 
Mamy tu do czynienia z koncepcją języka jako siły sprawczej, która może wpłynąć na zmianę stanu mentalnego i emocjonalnego odbiorcy i w tym sensie ekfraza (rozumiana jako enargeia/evidentia) jest fenomenem z gruntu retorycznym. Pojawiała się w antyku w różnych formach wypowiedzi i różnych postaciach: i w tekstach historyków, i w literaturze; zarówno w formie prozatorskiej, jak i wierszowanej; jako samodzielny tekst (epigramaty ekfrastyczne ${ }^{39}$ od III wieku p.n.e. przez ponad 400 lat były podstawowym przykładem tekstu ekfrastycznego) albo jako epizod czy interludium w większych formach wypowiedzi ${ }^{40}$. Ekfraza z pobocznego wtrętu często przeradzała się w figurę odwracającą uwagę od głównej narracji, spychając ją na drugi plan. Jej wyrazistość mogła przekładać się na uwypuklenie roli samego opisywanego dzieła lub mistrzostwa jego twórcy, jak w przypadku opisu tarczy Achillesa w Iliadzie.

Kwintesencję tej kultury stanowią Eikones Filostrata Starszego z początku III wieku ${ }^{41}$. Składają się na nie retoryczne opisy (najprawdopodobniej nieistniejących) 65 obrazów tablicowych z galerii neapolitańskiej, stworzone w poetyce tzw. drugiej sofistyki ${ }^{42}$.Zapoczątkowały one tradycję niezależnych, będących autonomiczną całością prozatorskich opisów dzieł sztuki. Stanowią początek historii ekfrazy jako formy genologicznej (nie zachował się bowiem pierwszy zbiór ekfraz opisujących dzieła sztuki, autorstwa Nikostratosa z Macedonii z połowy II wieku). Jak wskazuje Diana Shaffer, Filostrat zaadaptował schemat ekfrazy jako model dla swoich miniatur prozatorskich, a skorzystał przy tym z technik kompozycyjnych przybliżonych w progymnasmata i z teorii filozoficznych dotyczących phantasia rozwijanych przez sceptyków

Por. A Stavru Ekphrasis ed enargeia. Figurare tramite parole e dire tramite immagini, „estetica. studi e ricerche" $1 / 2013$, s. 5, przypis 1.

Jaś Elsner posługuje się na oznaczenie tych dwóch przypadków określeniami "self-standing ekphrasis" oraz "interventive ekphrasis”, a zagadnienie dwóch rodzajów ekfrazy omawia na przykładach starożytnych tekstów. Por. J. Elsner Introduction. The genres of ekphrasis, "Ramus. Critical Studies in Roman and Greek Literature" 2002 Vol. 31 Nos 1-2, s. 1-15.

41 Zagadnienie ekfraz Filostrata Starszego stanowi osobny przedmiot analizy w badaniach nad ekfrazą oraz nad literaturą antyczną. Por. m.in.: O. Schönberger Die »Bilder« des Filostratos w: Beschreibungskunst - Kunstbeschreibung..., s. 157-176; M. Conan The Imagines of Philostratus, "Word \& Image" 1987 Vol. 3 Iss. 2, s. 162-171; N. Bryson Philostratus and the Imaginary Museum, w: Art and Text in Ancient Greek Culture, s. 255-283; R. Popowski Retoryka w późnoantycznych opisach dziełsztuki, w: Retoryka antyczna i jej dziedzictwo, red. J. Axer, Aletheia, Warszawa 1996, s. 50-64.

Por. R. Popowski Starożytny przewodnik... 
i stoików ${ }^{43}$. W swoich ekfrazach stosuje określony schemat opisu: rzut oka na całość obrazu, koncentracja na wybranych szczegółach, dygresja na temat mitu, opis detali związanych z postaciami, powrót do mitycznej historii i jej konsekwencji. Przekazuje przy tym niewiele informacji na temat malarskich aspektów dzieła, ale za to łączy opis z opowiadaniem o losach postaci, o zdarzeniach (dopowiada historie, odnosząc się do mitologii, literatury i historiografii). Określa ponadto myśli, emocje i motywy działań postaci, czasami nawet przytacza „wypowiedzi” bohaterów. Pojawia się tu nie tylko sugestywny opis tego, co wizualne, ale też informacje o dźwiękach, zapachach, smakach i dotyku - tak że całość uzyskuje efekt synestezyjny. Ekfrazy Filostrata, oprócz aspektu deskryptywnego, imitacyjnego, charakteryzuje również element interpretacyjny, inwencyjny ${ }^{44}$. W rezultacie odbiorca czasem traci rozeznanie i nie wie, co miałby przedstawiać obraz, a co jest interpretacją mówiącego podmiotu. Co istotne dla rozwoju pojęcia ekfrazy w starożytności, Filostrat Starszy, a także inni retorzy sofiści, Katullus i Lukian, udoskonalili formę ćwiczenia retorycznego znanego z progymnasmata, nadali ekfrazie aspekty artystyczne, które powiązali z celami literackimi i ideowymi.

\section{Ekfraza starożytna versus ekfraza współczesna}

Ekfraza w antyku nie była pierwotnie rozumiana jako opis dzieła sztuki, a ponadto nie była nawet opisem w dzisiejszym znaczeniu (jeśli przyjąć kryteria tematu albo przedmiotu odniesienia i odróżnienie statycznego opisu od dynamicznej narracji). Enargeiczna ekfraza stanowiła przykład formy opisowo-opowiadającej, w której aspekt pragmatyczny stanowił warunek sine qua non jej istoty. Ważyła nie detaliczność deskrypcji, ale sugestywność w przywoływaniu danego przedmiotu odniesienia (choć opis w ekfrazie zwykle był jednak dość szczegółowy, często towarzyszyło mu wyliczenie lub akumulacja cech i elementów). Jak ujął to Alessandro Stavru:

43 D. Shaffer Ekphrasis and the Rhetoric of Viewing in Philostratus's Imaginary Museum, "Philosophy and Rhetoric" 1998 Vol. 31 No. 4, S. 303. Dominique Kunz w analizie ekfraz Filostrata mówi o dawanym przez tekst poczuciu obrazu, o pobudzaniu widzenia wewnętrznego i zauważa, że w koncepcję phantasia wpisane jest „podobieństwo wyobraźni i malowania bez użycia ręki”; D. Kunz Poczucie obrazu, przeł. T. Swoboda, w: Ut pictura poesis, red. M. Skwara, S. Wysłouch, słowo/obraz terytoria, Gdańsk 2006, s. 175, 176.

44 Por. D. Shaffer Ekphrasis and the Rhetoric of Viewing..., s. 304; M. Beaujour Some Paradoxes of Description, "Yale French Studies" 1981 No. 61, s. 31. 
Reprezentacja ekfrastyczna (poprzez słowa) jest więc efektywna o tyle, o ile jest w stanie tworzyć wypowiedź enargeiczna (przez obrazy). „Narzędzia”, które pozwalają na przejście ze sfery „werbalnej” do sfery „wizualnej” to z jednej strony zdolność postrzegawczo-odbiorcza wzroku, z drugiejmożliwości twórczo-aktywne intelektu ${ }^{45}$.

Tak pojmowana ekfraza jawi się jako swoista hybryda niepasująca do nowoczesnych klasyfikacji form podawczych i systematyzacji genologicznych. Ekfraza w dzisiejszym rozumieniu, po pierwsze, staje się formą dotyczącą konkretnych obiektów, a mianowicie dzieł sztuki. Zwykle sięga się do przykładu Filostrata i pojmuje ekfrazę jako utwór wierszem lub prozą opisujący dzieło sztuki, a zapomina o tradycji retoryki, zarówno greckiej, jak i rzymskiej. Po drugie, jest formą statyczną, zgodnie ze zwyczajowym rozumieniem opisu. Po trzecie - w osłabiony sposób działa na odbiorców. Rola odbiorcy była istotniejsza w starożytnych ekfrazach, jako że z założenia dopełniał on daną wypowiedź swoją aktywnością. Wyraźnie podejmowano w antyku również temat wizualności, nawet jeśli ekfraza nie dotyczyła dzieła sztuki. Takie ujęcie zagadnień nie jest typowe dla ekfraz współczesnych. Wiąże się to, co oczywiste, ze zmianą rzeczywistości materialno-umysłowej i społecznej, z odmiennym kontekstem kulturowym (dziś obca jest nam tradycja oralna oraz właściwe jej ćwiczenie pamięci i imaginacji); dołącza się tu dodatkowo kwestia różnych koncepcji języka, jego związku z rzeczywistością pozawerbalną i oddziaływaniem na słuchaczy czy czytelników.

Można nawet zapytać, czy w przypadku współczesnej ekfrazy (inaczej niż w antyku) zachodzi w ogóle potrzeba dokonywania rekonstrukcji bądź wizualizacji dzieła plastycznego przywołanego przez tekst, jeśli dzieło to istnieje i można je zobaczyć. Ze względu na dostępność oryginału i reprodukcji w XX wieku zdecydowanie zmienił się (w porównaniu z dawną historią sztuki i krytyką artystyczną) charakter dyskursu o artefaktach - zniknęła potrzeba ich szczegółowego opisywania, a w większej mierze interpretuje się je i dzieli własną perspektywą odbiorczą. Mamy tu do czynienia i z opisem (choć często zredukowanym) plastycznego modelu, którym najczęściej jest obraz, i z prezentacją uwag prowokowanych przez dzieło sztuki oddziałujące na piszącego.W ekfrazie celem nie jest stworzenie językowego ekwiwalentu danego wzorca plastycznego. Artefakt w pewnym sensie staje się narzędziem w danej wypowiedzi - kiedyś umożliwiającym porwanie widza, apelującym

A. Stavru Ekphrasis ed enargeia..., s. 7. 
do jego emocji i imaginacji, współcześnie w dużej mierze pozwalającym wyrazić się osobowości autora, jego emocjonalnej i intelektualnej wrażliwości. Nacisk przeniósł się więc z odbiorcy i sugestywności ekfrazy na piszącego i subiektywny wymiar interpretacji dzieła plastycznego. W konsekwencji pojawia się rozdźwięk między starożytnym a współczesnym pojmowaniem ekfrazy. Posługujemy się dziś starym terminem, ale wyposażamy go w nowe znaczenie $^{46}$.

Z zestawiania, a właściwie przeciwstawiania ekfrazie współczesnej ekfrazy starożytnej wynikają jednak pewne konfuzje. Znamienna pod tym względem jest propozycja Pawła Goglera. Nazywa on ekfrazami właściwymi te, które naśladują model Filostrata, i konstatuje, że tak rozumiana ekfraza już nie istnieje. Wydaje się jednak, że po pierwsze, nie pojmuje się tu dobrze ekfrazy Filostrata (tj. niewłaściwie ją charakteryzuje) ${ }^{47}$, po drugie - zapomina o starożytnej retorycznej koncepcji ekfrazy. Nietrafne wydaje się też charakteryzowanie ekfrazy współczesnej w odniesieniu do typologii Seweryny Wysłouch, która pisze o intertekstualnych nawiązaniach do sfery wizualnej ${ }^{48}$. W takim podejściu ekfrazą stają się bowiem wszystkie wypowiedzi, które dotykają sztuki. Nie znikają ponadto wątpliwości, czy ekfraza właściwa/starożytna to ekfraza z rozpraw m.in. greckich retorów $i$ Kwintyliana, a mianowicie figura retoryczna będąca unaoczniającym opisem, czy ekfraza Filostrata, tj. gatunek literacki, tyleż deskryptywny i plastycznie opowiadający, co subiektywnie

46 Dodatkowo ekfraza określana jako współczesna od połowy XX wieku także doświadczyła zawirowań konotacyjno-denotacyjnych. Najpierw bowiem dominowały definicje, które zawężały jej zakres tematyczny (czasem radykalnie: ekfraza jako poetycki opis obrazu lub rzeźby). Ostatnie dwie dekady przyniosły z kolei falę prac, w których ekfrazę odnosi się do nowych obszarów, jak film czy muzyka. Często rozszerza się stosowalność terminu tak, że ogarnia on bez mała wszystkie teksty dotyczące sztuki, bez względu na charakter relacji międzyartystycznych.

47 Ekfraza właściwa, zdaniem badacza, m.in. stanowi „całość od początku do końca związaną z wyglądem obrazu”; "aspekty interpretacyjne dzieła sztuki (jego znaczenie) nie są wyrażone dyskursywnie, lecz implikowane jedynie pośrednio przez opis"; a przecież u Filostrata pojawiają się interpretacje filozoficzno-estetyczne, znajdujące punkt wyjścia w widzianej scenie, retor posługuje się opisem zawierającym zwroty do odbiorcy i do bohaterów obrazu, opisuje dynamicznie, wprowadzając dialogi, ruch i doznania zmysłowe do przedstawień; nie daje nam systematycznych i wyczerpujących opisów, a często prezentuje subiektywne interpretacje. Por. P. Gogler Kłopoty z ekfrazq, w: Ruchome granice literatury. W kręgu teorii kulturowej, red. S. Wysłouch, B. Przymuszała, PWN, Warszawa 2009, s. 36, 37.

48 Por. S. Wysłouch O malarskości literatury, w: tejże Literatura i semiotyka, PWN, Warszawa 2001, S. $75-94$. 
interpretujący. Doprecyzowania wymaga pojmowanie ekfrazy dzisiaj, zwłaszcza w sytuacji rozmycia znaczenia i zakresu tej kategorii; wobec swoistego impasu w tym obszarze badacze uznają "osłabienie kwalifikacji gatunkowej"49 i stwierdzają,że pozostaje mówienie o „ekfrastyczności” tekstów ${ }^{50}$.W efekcie pozostajemy w kotle nieokreśloności i względności możliwych przypadków relacji słowno-obrazowych. Dlatego proponuję wydzielić subkategorie w ramach ogólnej kategorii interferencji interartystycznych: przyjąć operacyjną, z punktu widzenia praktyki twórczej i teorii literatury, nie nazbyt ogólną definicję ekfrazy, natomiast dla innych zjawisk zarezerwować osobne terminy. Chodziłoby więc o to, aby zrezygnować z operowania jednym ogólnikowym terminem zbiorczym i adekwatnie używać stosownych kategorii - mówić odpowiednio o ekfrazie, aluzji pikturalnej, przywołaniu stylu czy motywu malarskiego, hypotypozie ${ }^{51}$.

\section{Ekfrazy krytyczne i literackie (denotacyjne, konotacyjne, kombinacyjne)}

Wziąwszy pod uwagę najważniejsze dla badań nad ekfrazą kryteria, chciałabym zaproponować następującą rozszerzoną charakterystykę ekfrazy w jej rozumieniu współczesnym.

1) Ekfrazą jest werbalny opis danego realnego i jednostkowego dzieła sztuki wizualnej (obrazu, ryciny, rysunku, rzeźby, obiektu architektonicznego, fotografii) ${ }^{52}$, raczej nie dzieła fikcyjnego, czyli wytworu wyobraźni piszącego

Określenie Wysłouch, por. S. Wysłouch Ekfraza czy przekład intersemiotyczny?, w: Ruchome granice literatury..., s. 48-64.

Jak pisał Adam Dziadek: „Jeśli chodzi o teksty współczesne, to warto zaznaczyć, że często spełniają one wyznaczniki ekfrazy jedynie po części i trafniej byłoby mówić o ich ekfrastyczności czy ich charakterze ekfrastycznym"; A. Dziadek Apologia twórczej swobody. EsejeZbigniewa Herberta: opis - uobecnienie - interpretacja, w: Zmysł wzroku, zmysł sztuki. Prywatna historia sztuki Zbigniewa Herberta, cz. II, red. J.M. Ruszar, Wydawnictwo Archidiecezji Lubelskiej "Gaudium”, Lublin 2006, s. 39-40.

W mojej propozycji nazewniczo-systematyzacyjnej hypotypoza wciela cechy, jakie uosabiała ekfraza w antycznej retoryce - chodzi o pierwotny aspekt ekfrazy jako dynamicznie opowiadającej, sugestywnie reprezentującej, poruszającej wyobraźnię wizualną odbiorcy. W antyku hypotypoza była synonimem ekfrazy, jej enargetycznego, ewidencyjnego aspektu, dlatego aby odróżnić dzisiejszą ekfrazę od ówczesnej, stosuję termin hypotypoza jako oddający charakterystykę starożytnej ekfrazy (choć w odniesieniu już tylko do dzieł sztuki).

Opisów utworów muzycznych nie nazywam ekfrazami - owe dzieła muzyczne istnieją realnie, ale nie w wymiarze wizualnym (chyba że ekfraza miałaby nazywać opisy partytur muzycznych). Bardziej uzasadnione wydaje mi się operowanie pojęciem ekfrazy w odniesieniu 
(np. opartego na jakimś stylu czy tradycji szkoły malarskiej, stanowiącego wybiórczą kontaminację prac danego malarza albo prac różnych artystów dotyczących jednego tematu - takie przypadki byłyby przykładem "słabej” ekfrazy czy quasi-ekfrazy) $)^{53}$. Nie wystarczy sama aluzja do dzieła sztuki albo np. tylko podanie jego tytułu - aby mówić o ekfrazie, musi pojawić się zwerbalizowane odniesienie do formy i/lub treści przedstawienia plastycznego. 2) Najczęściej, ale nie zawsze, w ekfrazie pojawiają się wprost wskaźniki metatekstowe pozwalające na identyfikację dzieła stanowiącego przedmiot odniesienia; możemy więc mówić o ekfrazach eksplicytnych i implicytnych ${ }^{54}$. 3) Przywołanie artefaktu w ekfrazie nie jest kwestią przypadku, nie wynika $\mathrm{z}$ instrumentalnego podejścia do dzieła ani nie stanowi ozdobnika. Wiąże się to z rolą obrazu w tekście - artefakt jest inherentnym składnikiem partycypującym w budowaniu sensu i struktury danej wypowiedzi55.4) Ekfraza to nie tylko mniej lub bardziej precyzyjny i wierny opis oraz objaśnienie dotyczące zarówno treści przedstawienia wizualnego, jak i (zwykle w mniejszym stopniu i rzadziej) materialnych i formalnych walorów dzieła; można odróżnić ekfrazy deskryptywne, dokładnie opisujące i objaśniające, oraz ekfrazy selektywne, czyniące to wybiórczo. Ekfraza to również (choć nieobligatoryjnie) komentarz będący interpretacją i przedstawieniem punktu widzenia oglądającego, który staje się piszącym. 5) Ekfraza istnieje jako osobny utwór albo fragment większego dzieła, w trzech rodzajach literackich i powiązanych z nimi gatunkach, również w gatunkach pogranicznych, jak esej, a także w krytyce sztuki (której zresztą niektóre przykłady można by

do filmowych adaptacji dzieł sztuki, czyli transpozycji sztuki wizualnej na sztukę wizualno-werbalno-dźwiękową.

53 Niektórzy badacze uznają opisy nieistniejących realnie artefaktów za ekfrazy. Słynne jest dokonane przez Hollandera wydzielenie, ze względu na ontologię referenta, ekfraz imaginacyjnych (notional ekphrasis) oraz rzeczywistych (actual ekphrasis); por. tegoż The Poetics of Ekphrasis, "Word \& Image” 1988 Vol. 4 Iss. 1, s. 209-219. Podobnie odróżnia ekfrazy fikcyjne (fictional; tworzące, a nie opisujące dzieło) od faktycznych (factual) filolog klasyczny Andrew Laird; por. tegoż Sounding Out Ecphrasis: Art and Text in Catullus 64, "The Journal of Roman Studies" 1993 Vol. 83 , s. $18 \mathrm{in}$.

Por. A. Dziadek Obrazy i wiersze. Z zagadnień interferencji sztuk w polskiej poezji współczesnej, Wydawnictwo UŚ, Katowice 2004, s. 54, 55.

55 Por. wskazane przez Liliane Louvel funkcje obrazu w tekście: obraz może być integralnym albo incydentalnym, znaczącym (emblematic) albo dekoratywnym elementem struktury; L. Louvel From Text to Iconotext: Degreed of Pictorial Saturation, w: tejże Poetics of the Iconotext, trans. by L. Petit, Ashgate, Burlington 2011, s. 73-100. 
ulokować w strefie gatunków pogranicznych, jako mające walory i naukowe, i artystyczne, i publicystyczne).

Wydaje się ponadto, że w odniesieniu do ekfrazy dzisiejszej sensowne byłoby stosowanie prostego podziału uwzględniającego funkcję ekfrazy. Taki jest projekt Riffaterre'a, który odróżnia ekfrazy literackie (w utworach literackich) od ekfraz krytycznych (w tekstach krytyków i historyków sztuki) ${ }^{56}$. Ekfraza krytyczna według badacza jest ufundowana na analizie formalnej swojego przedmiotu, formułuje sądy odnoszące się do konkretnych zasad estetycznych i reguł artystycznych. Z kolei ekfraza literacka - na idei obrazu („sur une idée du tableau”), na obrazie artysty („sur une image de l'artiste"), na językowym locus communis dotyczącym sztuki; niejednokrotnie odgrywa w utworze rolę symboliczną. W moim przekonaniu oba typy ekfrazy zawierają element subiektywnej interpretacji, choć indywidualna wrażliwość piszącego w większym stopniu ujawnia się bez wątpienia w ekfrazie literackiej ${ }^{57}$. Do kategorii ekfrazy literackiej, oprócz utworów literackich wierszem i prozą, zaliczam również eseje literatów opisujące artefakty (eseje z podróży, eseje refleksyjno-filozoficzne, eseje zapiski dziennikowe albo autobiograficzne), gdyż stanowią tekstową formę pograniczną o wysokim walorze artystycznym, nasyconą literackością i wychodzącą spod ręki pisarza albo poety, który staje się w konsekwencji twórcą dwuręcznym.

Ekfrazy krytyczne określiłabym jako użytkowe, dydaktyczne, opisowe i wyjaśniająco-komentatorskie. Najmocniejszy jest w nich aspekt imitacyjno-informacyjny względem danego dzieła sztuki. Tymczasem ekfrazy

56 M. Riffaterre L'illusion d'ekphrasis, w: La pensée de l'image. Signification et figuration dans le texte et dans la peinture, sous la direction de G. Mathieu-Castellani, Presses Universitaires de Vincennes, Saint-Denis 1994, s. 211-212. Podobne odróżnienie, ale z innej perspektywy metodologicznej, przeprowadza Stanisław Balbus, który wydziela ekfrazę ikonograficzną, właściwą historii sztuki, od ekfrazy poetyckiej (nie odnosi się do ekfraz prozatorskich, ale idea jego podziału jest taka sama jak w przypadku ekfrazy krytycznej i literackiej). Celem tej drugiej jest „znaczeniotwórczy rezonans, przeto zawsze w relacji tekstu z jego wizualnym «oryginałem» różnica zdecydowanie wysuwa się przed powtórzenie i «podobieństwo»"; S. Balbus Rozwiq̨zywanie ekfrazy (prywatna historia interpretacji jednego wiersza Zbigniewa Herberta), w: Kulturowe wizualizacje doświadczenia, s. 118.

Zajmujący się ekfrazą zwracają uwagę na przefiltrowanie właściwie każdej ekfrazy przez jednostkowość piszącego. Jak ujmuje to Grant F. Scott: „Any observation or description of an object cannot avoid being inflected by the viewer's identity and cultural background. A plain ekphrasis is thus rhetorician's dream"; G.F. Scott The Rhetoric of Dilation: Ekphrasis and Ideology, „Word \& Image" 1991 Vol. 7 No. 4, S. 301, 304. 
literackie to wypowiedzi artystyczne, rodzaj mowy zastępczej, ekwiwalentyzującej - w tym sensie, że opisywanie dzieła staje się w dużym stopniu mówieniem o sobie, ujawnianiem indywidualności odbioru, dzieleniem się komentarzem filozoficznym. W pewnym sensie dzieło sztuki stanowi w nich pretekst do pisania o kwestiach bliskich autorowi, choć mających w artefakcie punkt zaczepienia. Dominuje tu aspekt interpretacyjny, co nie oznacza jednak, że nie występuje modus opisu obrazu.

Warto w tym punkcie skorzystać z rozróżnień translantologów, tym bardziej że istnieje obwarowanie dla korzystania z języka traduktologii w pojmowaniu ekfrazy jako rodzaju przekładu intersemiotycznego. Wszak ekfraza pierwotnie to tłumaczenie, czyli zarówno objaśnianie, jak i przekładanie - czegoś niezrozumiałego na inny język i w innej „kulturze tekstowej”58. Przekład wierny reprezentowałaby ekfraza krytyczna (użytkowa, dydaktyczna, źródłowa), wierna tekstowi wyjściowemu, opisująca i wyjaśniająca dzieła sztuki, obejmująca teksty z zakresu historii sztuki, zarówno naukowe, jak i publicystyczne i eseistyczne ${ }^{59}$. Przekład niewierny konkretyzuje ekfraza literacka (nieużytkowa, pretekstowa, docelowa), w której tekst źródłowy, tj. dzieło sztuki, jest pretekstem dla tekstu docelowego. Obejmuje ona, w moim ujęciu, teksty literackie i eseje pisarzy. Pierwszy typ ekfrazy, skojarzonej z językiem historii sztuki, wiąże się z domestykacją. Tekst wyjściowy zostaje bowiem udomowiony i pozbawiony obcości, w pewnym sensie dzieło sztuki pozostaje na gruncie macierzystej kultury, a przynajmniej zostaje oswojone (opisane, objaśnione) przez najbliższą mu dyscyplinę. Drugi typ natomiast kojarzy się z defamiliaryzacją (forenizacją), a więc z różnego typu deformacjami tekstu wyjściowego, z wprowadzaniem, ze względu na cele i funkcje tekstu docelowego, obcych mu elementów ${ }^{60}$ - bagażu subiektywnej perspektywy i przejawów obecności w tekście podmiotu patrzącego; opis w tym przypadku powiązany jest zwykle z aktem interpretacyjnym, mniej lub bardziej autorytarnym i spekulatywnym.

58 Por. T. Bilczewski Komparatystyka i interpretacja. Nowoczesne badania porównawcze wobec translatologii, Universitas, Kraków 2010, s. 116.

59 Nie jest to odosobniony pogląd. Por. I. Boyd Whyte, C. Heide Art History and Translation, "Diogenes" 2011 Vol. 3 No. 231, s. 45 i J. Elsner Art History as Ekphrasis, "Art History” 2010 Vol. 33 Iss. 1, S. 12.

60 Por. L. Venuti Invisibility, w: tegoż The Translator's Invisibility. A History of Translation, Routledge, London-New York 1995, s. 1-42, gdzie m.in. pojawia się rozróżnienie dwóch praktyk tłumaczenia: "domesticating" "foreignizing". 
Wśród ekfraz literackich wydzielam trzy główne typy: ekfrazy denotacyjne, konotacyjne i kombinacyjne (kompleksowe) ${ }^{61}$. Rozdzielenie denotacji od konotacji wiąże się z obserwacją (wynikającą z lektury opisów dzieł sztuki w tekstach eseistycznych i typowo literackich), że często piszący koncentrują się na jednym aspekcie artefaktu. Skupiają się:1) na denotacji - kiedy ześrodkowują swoją uwagę na plastycznym modelu jako desygnacie, tzn. ujmują go od strony technicznej, formalnej i w zakresie podstawowego opisu, który obejmuje to, co widać na obrazie; uwidaczniają się tutaj aspekty kojarzone z ekfrazą krytyczną, użytkową; 2) na konotacji - gdy opisują artefakt w jego wymiarze znaczeniowym - opis przechodzi w interpretację wykraczająca poza to, co pokazane wprost w danym dziele, obejmuje egzegezy i asocjacje prywatne, choć umocowane w źródłowym dziele, a także indywidualne doświadczenia powiązane z obiektem; tutaj ekfraza wyraźnie ciąży ku modelowi ekfrazy literackiej, pretekstowej. Ekfrazy kompleksowe/kombinacyjne łączą zaś oba typy deskrypcji. Wszelkie układy pośrednie klasyfikowałabym jako ciążące ku jednej ze wskazanych form lub łączące owe formy w specyficznych konfiguracjach.

Jeśli chodzi o ekfrazy krytyczne, to z założenia powinny być ekfrazami scalającymi denotację z konotacją, a więc ekfrazami niejako pełnymi. Konotacje oscylują w tym przypadku wokół tego, co wynika wprost z przedstawienia malarskiego albo z ustaleń stosownej specjalistycznej dziedziny (poza poddziedzinami w ramach historii sztuki, jak historia mody, ogrodów, koloru, teoria sztuki), która pozwala wyklarować niejasności czy zawiłości dostrzegane w artefakcie (jak historia społeczna, filozofia, teologia, literatura, historia nauki).

\begin{tabular}{|l|l|}
\hline \multicolumn{2}{|c|}{ Ekfraza } \\
\hline $\begin{array}{l}\text { ekfraza krytyczna - użytkowa/dydak- } \\
\text { tyczna }\end{array}$ & $\begin{array}{l}\text { ekfraza literacka - nieużytkowa/pre- } \\
\text { tekstowa }\end{array}$ \\
\hline $\begin{array}{l}\text { z założenia kompletna, tj. denotacyjno- } \\
\text {-konotacyjna }\end{array}$ & $\begin{array}{l}\text { trzy zasadnicze typy: } \\
\text { denotacyjna, konotacyjna, kombina- } \\
\text { cyjna }\end{array}$ \\
\hline
\end{tabular}

61 Stosuję nazwy funkcjonujące na gruncie logiki i semiotyki, gdyż najlepiej oddają one sens oddzielenia, o jaki mi chodzi. Trzeba jednak zastrzec, że skoro używam ich nie do nazw w języku, a do konkretnych obiektów, siłą rzeczy ich rozumienie nie będzie w pełni pokrywało się z tym znanym z logiki. 
Proponuję powyższą typologię jako użyteczną w charakteryzowaniu tekstów, w których pojawiają się deskrypcje artefaktów. Pozwala ona uwypuklić kluczowe składowe wypowiedzi opisującej dzieła sztuki, wydobyć i nazwać różnice w trybach deskrypcji stosowanych do konkretnych plastycznych modeli u poszczególnych twórców.

\section{Abstract}

\section{Rozalia Słodczyk}

INDEPENDENTSCHOLAR

Returning to Ekphrasis: A Possible Systematization and Typology

Słodczyk takes a comparative approach to re-examine our understanding of ekphrasis and to propose an operational typology. First she draws on influential definitions of ekphrasis by scholars such as Spitzer, Hollander, Krieger, Heffernan, Mitchell, Clüver and Webb, then she looks back at the sources and examines the Antique rhetorical tradition, i.e. the Greek progymnasmata, Quintilian's Institutio oratoria and Eikones (or Images) by Philostratus of Lemnos. The ancient understanding of ekphrasis, linked to figures of visualization such as enargeia and hypotyposis, is confronted with contemporary perspectives. This allows Słodczyk to highlight similarities as well as differences, and to identify the semantic shift that has taken place in definitions of ekphrasis. In the final part of the article she offers a prescriptive take on ekphrasis and proposes a systematization based, for instance, on translation studies, with a division into critical and literary ekphrasis, whereby the latter is again categorized into connotational, denotational and combinational ekphrasis.

\section{Keywords}

ekphrasis, enargeia, progymnasmata, rhetorics, translation 